\title{
The Influence of Work Stress and Discipline on Work Performance of Emplyee at PT. Surya Menara Pratama Jakarta Selatan
}

\author{
Rahmi Hermawati ${ }^{1}$, Sri Handayani ${ }^{2}$, \\ 1.2 Universitas Pamulang \\ E-mail: riskaafriyanti25@gmail.com
}

(Received: December-2017; Reviewed: January-2018; Accepted: February-2018;

Avalaibel Online: February-2018; Published: March-2018)

(7) This is an open access article distributed under the Creative Commons Attribution License

EY NC CC-BY-NC-4.0 @2018 by author (https://creativecommons.org/licenses/by-nc/4.0/)

\begin{abstract}
The final measure of success of an HR Department is work performance. The purpose of this study was to determine how much influence work stress has on work performance of empolyee at PT Surya Menara Pratama, South Jakarta, to find out how much influence discipline has on employee performance at PT Surya Menara Pratama, South Jakarta, and to determine the Effect of Work Stress and Discipline Towards Employee Job Performance at PT Surya Menara Pratama, South Jakarta. The research method used is a quantitative method with descriptive explanation. The population in this study were employees of PT Surya Menara Pratama South Jakarta with a sample of 60 and the sampling technique used was the Simple Random Sampling technique. Furthermore, the analysis method used in this study is multiple linear regression analysis consisting of descriptive analysis of the questionnaire, validity test, reliability test, classic assumption test, coefficient of determination test correlation coefficient test, simple regression test, multiple linear regression test, $t$ test (test partial), $\mathrm{f}$ test (simultaneous test). The results of simple linear regression analysis show that work stress has a significant effect on work performance with a tcount of 3.902, a significance value of 0.000 , a regression coefficient of 0.436 and a regression equation $\mathrm{Y}=24.167+0.436 \mathrm{X} 1$. The results of simple linear regression analysis show that work discipline has a significant effect on work performance with a tcount of 3,500, a significance value of 0.001 , a regression coefficient of 0.400 and a regression equation $\mathrm{Y}=25.804+0.400 \mathrm{X} 2$. The results of multiple linear regression analysis show that work stress and work discipline simultaneously have a significant effect on work performance with a Fcount of 10.923 , a significance value of 0.000 , a coefficient of determination of 0.252 and a regression equation $\mathrm{Y}=17.293+0.332 \mathrm{X} 1+0.273 \mathrm{X} 2$.
\end{abstract}

Keywords: Work Stress; discipline; job performance

\section{INTRODUCTION}

The final measure of success of an HR Department is work performance (Den Hartog \& Verburg, 2004; Gelade \& Ivery, 2003; Koopmans, 2014; Rambli Bin Haji Hasbi, 2001). Because both the department itself and employees need feedback on their efforts and 
contributions according to the evaluation criteria determined by the company or institution. Therefore work performance appraisal is a process whereby organizations evaluate or assess work performance The company requires employees who have high performance (Bangun, 2012; Douglas, 2010; Notoatmojo, 2010; Yani, 2011). Therefore the company must be able to encourage to increase the potential of its employees and at the same time minimize risks that can reduce employee performance, including work stress.

In every life in this world, humans are not free from all problems. Problems that arise if not resolved properly, it will cause frustration and stress. In the world of work, we often miss employees who experience frustration and stress (Dhania, 2010; Irvianti \& Verina, 2015; Prihatini, 2008; Tunjungsari, 2011). Job stress in problems experienced by employees tends to arise more easily than overcoming it, because of that work stress will not arise if there is no trigger, work stress can be seen from the sounds that emerge from employees such as the emergence of complaints about work problems (Afrizal, Musadieq, \& Ruhana, 2014; Dewi \& Netra, 2015; Lindawati, 2014; Setiyana, 2013)

Stress is the cause of employee emotions is unstable, and therefore causes employees to not work optimally (Habibi \& Jefri, 2018; Han \& Ketut Netra, 2014; Othman, 2015; Waspodo, Handayani, \& Paramita, 2013). The current condition will increase when it will occur in the company that will come. Job stress is one of the most important of work performance or achievement (Ali, 2011; Musliha Fitri, 2013; Wartono, 2017; Wibowo, Riana, \& Putra, 2015). Therefore, every company needs to create a conducive work environment so that it can reduce the number of employee work stress (Sunarsi, 2018).

Employee discipline will affect the efficiency and effectiveness of work in achieving company goals. Employee performance at PT. Surya Menara Pratama, South Jakarta, has not maximally met the criteria set by the company, only reaching $77 \%$. The lack of alertness of employees in serving customers also has an impact on decreasing employee performance. The observations also show that there are employees who get heavy workloads while the reciprocity received is not as expected. Besides the high pressure from the leadership often makes employees feel mentally depressed, which then makes employees feel stressed with their work. The stress caused the lack of employee discipline, empirical data shows the high level of employees who are absent, sick, permitted and late. This, of course, can disrupt the operational activities in PT. Surya Menara Pratama where there are some employees who want to leave the company, causing the company's performance to be not optimal in achieving its goals.

Starting from the phenomena that arise in PT. PT. Surya Menara Pratama must strive to overcome these problems, especially in terms of reducing stress due to high work causes and finding solutions for the creation of high work discipline, so that employee work performance remains good and the company's existence is maintained.

\section{METHOD}

The method used is quantitative associative, according to (Sugiyono, 2017), the associative method is a research method designed to determine the effect or relationship between two other variables. In this study, the population used was employees at PT. Surya Menara Pratama with a total of 150 people. And to determine the number of samples, the researchers used the Slovin formula. From the calculation of the Slovin formula with an error rate of 5\%, the sample obtained was 60 respondents. The data used in this study are primary data and secondary data. According (Sugiyono, 2016), primary data or raw data is data that is processed when the data 
collection is done directly to the field. While secondary data is data whose collection process is carried out by gathering documents in the relevant agency or institution, written sources or the internet. The techniques used in research are observation, interview, and distribution of the questionnaire with a Likert scale. Data analysis methods used are validity test, reliability test, classic assumption test (normality test, homogeneity, autocorrelation, multicollinearity, and heteroscedasticity), multiple linear regression, coefficient of determination and hypothesis testing.

\section{RESULT AND DISCUSSION}

The purpose of this study was to determine the effect of work stress on employee work performance, the effect of work discipline on employee work performance, and the effect of work stress and discipline on employee work performance

\section{Validity and Reliability Test}

Table 1.

Validity Test Results $\mathrm{X}_{1}, \mathrm{X}_{2}$ dan $\mathrm{Y}$

\begin{tabular}{|c|c|c|c|c|c|}
\hline Statement & $\begin{array}{c}\text { R calculed X1 } \\
\text { (Work Stress) }\end{array}$ & $\begin{array}{c}\text { R calculed X2 } \\
\text { (Discipline) }\end{array}$ & $\begin{array}{c}\text { R calculed Y (Work } \\
\text { Performance) }\end{array}$ & R table & Description \\
\hline item 1 & 0,595 & 0,429 & 0,442 & 0,254 & Valid \\
\hline item 2 & 0,658 & 0,421 & 0,407 & 0,254 & Valid \\
\hline item 3 & 0,563 & 0,359 & 0,5 & 0,254 & Valid \\
\hline item 4 & 0,432 & 0,511 & 0,582 & 0,254 & Valid \\
\hline item 5 & 0,56 & 0,641 & 0,64 & 0,254 & Valid \\
\hline item 6 & 0,505 & 0,643 & 0,588 & 0,254 & Valid \\
\hline item 7 & 0,575 & 0,548 & 0,773 & 0,254 & Valid \\
\hline item 8 & 0,535 & 0,513 & 0,668 & 0,254 & Valid \\
\hline item 9 & 0,381 & 0,777 & 0,492 & 0,254 & Valid \\
\hline item 10 & 0,668 & 0,716 & 0,692 & 0,254 & Valid \\
\hline
\end{tabular}

Sumber: Data Primer diolah

Table 1 shows that each statement in the work stress questionnaire (X1), discipline (X2) and employee performance was stated as valid because it was greater than $r$ table. Because the validity assumptions are fulfilled, the data in this study can be analyzed at a later stage.

Table 2

Reliability Test Results 


\begin{tabular}{|c|l|c|c|c|}
\hline No. & \multicolumn{1}{|c|}{ Variabel } & $\begin{array}{c}\text { Coeficient } \\
\text { Alpha }\end{array}$ & $\begin{array}{c}\text { Standar } \\
\text { Cronbatch } \\
\text { Alpha }\end{array}$ & Decision \\
\hline 1 & Work Stress (X1) & 0,742 & 0,6 & Reliable \\
\hline 2 & Discipline (X2) & 0,752 & 0,6 & Reliable \\
\hline 3 & Performance (Y) & 0,769 & 0,6 & Reliable \\
\hline
\end{tabular}

Based on the table 2, it is known that all variables (work discipline, work stress, and work performance) have a Cronbach alpha value greater than (>) than 0.60 so it can be concluded that the variable questionnaire in this study is reliable and can be continued in subsequent analyzes ( Regression analysis).

\section{Classic Assumption Test}

Table 3.

Data Normality Test

One-Sample Kolmogorov-Smirnov Test

\begin{tabular}{|c|c|c|c|c|}
\hline & & $\begin{array}{l}\text { Disiplin } \\
\text { kerja }\end{array}$ & Stres kerja & Prestasi kerja \\
\hline \multicolumn{2}{|l|}{$N$} & 60 & 60 & 60 \\
\hline & Mean & 42.26 & 43.84 & 44.18 \\
\hline \multirow[t]{2}{*}{ Normal Parameters ${ }^{a, b}$} & $\begin{array}{l}\text { Std. } \\
\text { Deviation }\end{array}$ & 5.110 & 4.400 & 4.676 \\
\hline & Absolute & .169 & .104 & .130 \\
\hline \multirow{2}{*}{$\begin{array}{l}\text { Most Extreme } \\
\text { Differences }\end{array}$} & Positive & .065 & .081 & .107 \\
\hline & Negative & -.169 & -.104 & -.130 \\
\hline Kolmogorov-Smirnov Z & & 1.196 & .738 & .916 \\
\hline Asymp. Sig. (2-tailed) & & .114 & .648 & .370 \\
\hline
\end{tabular}

Source: Data processed with IBM SPSS version 22

Based on the table above, it is known that the Asymp value. Sig. (2-tailed) work discipline variable of 0.114 , Asymp value. Sig. (2-tailed) work stress is 0.648 and Asymp value. Sig. (2tailed) work performance of 0.370 . The three variables in the normality test using the Kolmogorov-Smirnov Test method have an Asymp Sig value greater than the minimum criterion of 0.05 (Ghozali, 2015), so it can be concluded that all variables in this study meet the normality criteria.

Table 4.

Auto Correlation Test 


\begin{tabular}{|c|c|c|c|c|c|}
\hline \multicolumn{6}{|c|}{ Model Summary ${ }^{b}$} \\
\hline Model & $\mathrm{R}$ & R Square & $\begin{array}{l}\text { Adjusted R } \\
\text { Square }\end{array}$ & $\begin{array}{c}\text { Std. Error } \\
\text { of the } \\
\text { Estimate }\end{array}$ & Durbin-Watson \\
\hline 1 & $.526^{a}$ & .277 & .252 & 3.253 & 2.002 \\
\hline
\end{tabular}

a. Predictors: (Constant), Work Stress, Discipline

b. Dependent Variable: Work Performance

Source: Processed Data SPSS Version 22

Based on the table above it is known that the DW value of 2.011 is greater than the DU table of 1.651 and smaller than 4 - DU $(4-1,651=2,349)$, it can be concluded that there is no correlation between independent variables.

\section{Table 5.}

Multicollinearity Test

\begin{tabular}{|r|r|r|}
\hline \multirow{2}{*}{ Model } & \multicolumn{2}{|c|}{ Collinearity Statistics } \\
\cline { 3 - 4 } & Tolerance & \multicolumn{1}{c|}{ VIF } \\
\hline (Constant) & & \\
1 Stres Kerja & .853 & 1.172 \\
Disiplin Kerja & .853 & 1.172 \\
\hline
\end{tabular}

Version 22

Source: Processed Data SPSS

Mutilolinearity test is done to prove that between independent variables do not have multicollinearity or do not have a correlation relationship between independent variables. Based on data testing results using tolerance values and VIF shows that the tolerance value is smaller than 1.00 and the VIF value is smaller than 10. This can be interpreted that there is no Multicollinearity in this study.

Figure 1.

Heteroscedasticity Test 


\section{Scatterplot}

\section{Dependent Variable: Prestasi Kerja}

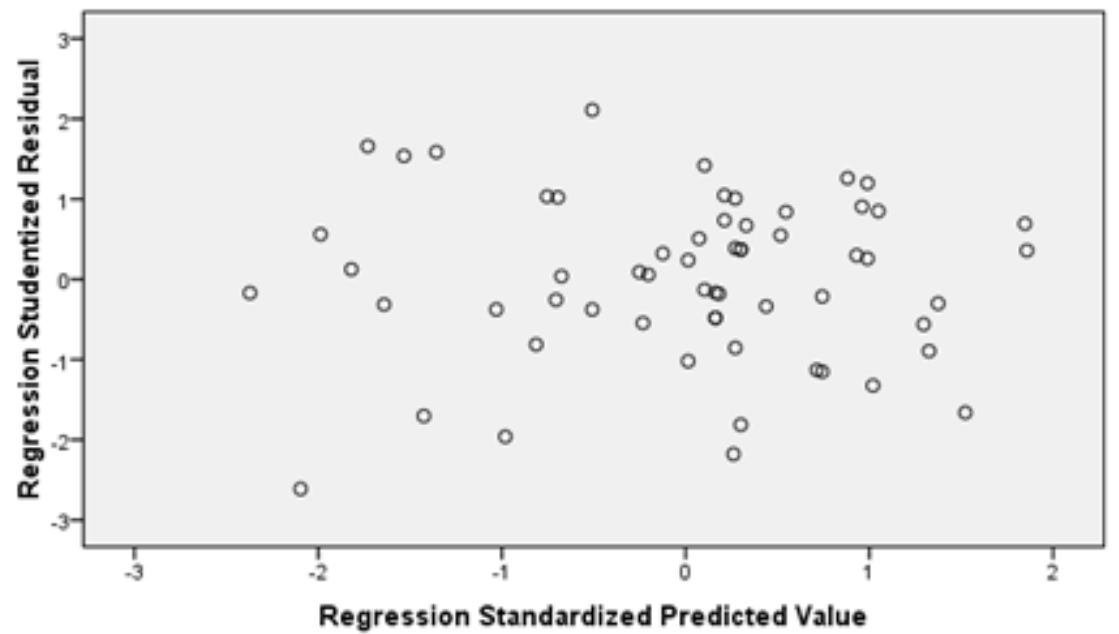

Source: Processed Data SPSS Version 22

Based on Figure 1, it is known if the data is spread evenly on both positive and negative spaces. Then it can be concluded if the data in this study have met the assumption of heteroscedasticity.

\section{Coefficient of Determination}

Table 6.

Coefficient of Determination

Determination Coeffisien of Work Stress $\left(\mathbf{X}_{1}\right)$ dan Discipline $\left(\mathbf{X}_{2}\right)$

on Work performance (Y)

Model Summary ${ }^{\mathrm{b}}$

\begin{tabular}{|r|r|r|r|r|r|}
\hline Model & \multicolumn{1}{|c|}{$\mathrm{R}$} & $\mathrm{R}$ Square & $\begin{array}{c}\text { Adjusted R } \\
\text { Square }\end{array}$ & $\begin{array}{r}\text { Std. Error of } \\
\text { the Estimate }\end{array}$ & $\begin{array}{c}\text { Durbin- } \\
\text { Watson }\end{array}$ \\
\hline 1 & $.526^{2}$ & .277 & .252 & 3.253 & 2.002 \\
\hline
\end{tabular}

a. Predictors: (Constant), Work Stress, Discipline

b. Dependent Variable: Work Performnace

Source: Processed Data SPSS Version 22

Based on the table above, the value of the contribution of the variable work stress and work discipline to work performance is 0.252 . This means that job stress and work discipline have the 
ability to explain work performance variables by $25.2 \%$ while the remaining $74.8 \%$ is explained by other variables outside this study.

\section{Regression Analysis}

Multiple regression analysis is used to find out how much influence the independent variable (Independent), namely: work stress (X1), and work discipline (X2) on the dependent variable (Dependent) of employee performance (Y).

Tabel 7.

Regression of Work Stress ( $\mathrm{X}_{1)}$ and Discipline $\left(\mathrm{X}_{1}\right)$ on Performance $(\mathrm{Y})$

\begin{tabular}{|r|r|r|r|r|r|}
\hline \multirow{2}{*}{ Model } & \multicolumn{2}{|c|}{$\begin{array}{l}\text { Unstandardized } \\
\text { Coefficients }\end{array}$} & $\begin{array}{c}\text { Standardized } \\
\text { Coefficients }\end{array}$ & \multirow{2}{*}{ t } & \multicolumn{1}{c|}{ Sig. } \\
\cline { 2 - 4 } & \multicolumn{1}{|c|}{ B } & Std. Error & \multicolumn{1}{c|}{ Beta } & & \\
\hline (Constant) & 17.293 & 5.359 & & 3.227 & .002 \\
1 Stres Kerja & .332 & .117 & .347 & 2.846 & .006 \\
$\begin{array}{c}\text { Disiplin } \\
\text { Kerja }\end{array}$ & .273 & .117 & .285 & 2.335 & .023 \\
\hline
\end{tabular}

Source: Processed Data SPSS Version 22

Based on the results of these calculations it can be obtained as follows: $\mathrm{Y}=17,293+0.332 \mathrm{X} 1+0.273 \mathrm{X} 2$

A constant value of 17.293 means that if the variables of work stress (X1) and discipline (X2) are in a constant state, then the performance of employees (Y) is equal to 17.293. A regression value of $0.332 \mathrm{X} 1$ means that if the motivation variable (X1) increases by 1 unit and the discipline variable (X2) remains, then the employee's performance $(\mathrm{Y})$ will increase by 0.332 units. A regression value of $0.273 \mathrm{X} 2$ means that if the discipline variable (X2) increases by 1 unit, and the motivation variable (X1) remains, then the employee's performance (Y) will increase by 0.273 units.

\section{Correlation Coefficient}

The results of testing the correlation coefficient of this study can be seen in the following SPSS 22 output:

Tabel 8.

Correlation Coeffisien 


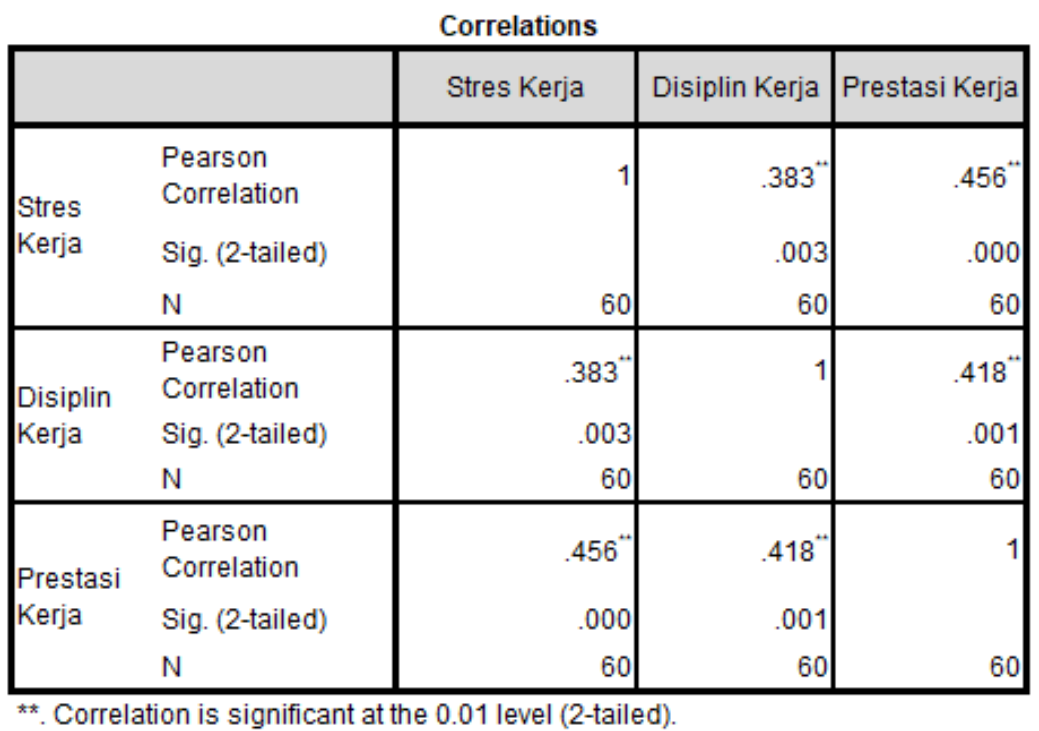

Source: Processed Data SPSS Version 22

Based on table 8 , it can be stated that the correlation value between work stress and work performance is 0.456 in the "medium" category. While the correlation value of the work discipline variable with the work performance of 0.418 falls into the "medium" category. In other words, there is a moderate/strong relationship between work stress variables and work discipline with work performance.

\section{Hypothesis Test Results}

Hypothesis testing is done in two stages, namely partial testing, and simultaneous testing. Based on the results of data processing, it can be put forward a simple linear regression equation as follows: from the results of data processing known regression equations, $t$ arithmetic, and significance as follows:

Regression Equation $\mathrm{Y}=24.167+0.436 \mathrm{X} 1$

$\mathrm{T}$ count $=3.902$

Significant Value $=0,000$

Based on the above findings, it can be stated that testing this hypothesis is that work stress has a tcount greater than t table $(3,902>2,002)$, so it can be concluded that $\mathrm{H} 0$ is rejected and $\mathrm{Ha}$ is accepted. Thus, work stress is proven to have a significant effect on work performance.

The results of data processing above are known to the regression equation, t-count and significance as follows:

Regression Equation $\mathrm{Y}=25.804+0.400 \mathrm{X} 2$

T count $=3,500$

Significant Value $=0.001$

Based on the above findings, it can be stated that testing this hypothesis is that work discipline has a tcount greater than t table $(3,500>2,002)$, so it can be concluded that $\mathrm{HO}$ is rejected and $\mathrm{Ha}$ is accepted. Thus, $\mathrm{m}$ that work discipline is proven to have a significant effect on work performance. 
This test is performed using the $\mathrm{F}$ distribution by comparing the calculated $\mathrm{F}$ value and the $\mathrm{F}$ table value. If the calculated $\mathrm{F}$ value $>$ Ftable, then $\mathrm{H} 0$ which states that the variation in the change in the value of the independent variable (work stress and discipline) cannot explain the change in the value of the dependent variable (employee work persuasion) is rejected and vice versa.

Table 9.

F test

ANOVA $^{\mathrm{b}}$

\begin{tabular}{|c|c|c|c|c|c|}
\hline Model & $\begin{array}{c}\text { Sum of } \\
\text { Squares }\end{array}$ & Df & $\begin{array}{l}\text { Mean } \\
\text { Square }\end{array}$ & $\mathrm{F}$ & Sig. \\
\hline Regression & 231.135 & 2 & 115.568 & 10.923 & $.000^{3}$ \\
\hline${ }^{1}$ Residual & 603.048 & 57 & 10.580 & & \\
\hline Total & 834.183 & 59 & & & \\
\hline
\end{tabular}

a. Predictors: (Constant), Disiplin Kerja, Stres Kerja

b. Dependent Variable: Prestasi Kerja

Source: Processed Data SPSS Version 22

Based on table 9, the calculated $\mathrm{F}$ count is 10.293 with a significance level of $0.000<0.05$. While the $\mathrm{F}_{\text {table }}$ value is 3.10 (from the calculation $\mathrm{dk} 1=2=0.05$ and $\mathrm{dk}=60-2-1=57$ obtained $F$ table 3.16). This means that the value of $F_{\text {count }} 10.293>F_{\text {table }} 3.10$ with a significance of 0.000 $<0.05$ thus Ho is rejected and $\mathrm{Ha}$ is accepted, which means work stress (X1) and work coordination (X2) of simultaneous or joint cooperation and significant on performance employees at PT. Surya Menara Pratama South Jakarta.

\section{CONCLUSION}

The results showed the contribution of work stress and work discipline to work performance by $25.2 \%$ and the remaining $74.8 \%$ explained by other variables outside this study. It is hoped that further researchers will use other variables such as compensation, leadership, competence, etc. so that the results become more comprehensive.

\section{REFERENCES}

Afrizal, P. R., Musadieq, M. Al, \& Ruhana, I. (2014). Pengaruh Konflik Kerja dan Stress Kerja terhadap Kepuasan Kerja (Studi pada Karyawan PT. TASPEN (PERSERO) Cabang Malang). Jurnal Administrasi Bisnis (JAB).

Ali, R. (2011). Faktor-Faktor Yang Mendorong Tekanan Kerja ( Stres ) Di Kalangan Guru-Guru Sekolah Menengah Di Daerah Pasir Puteh. Master of Education Open University Malaysia 
2011.

Bangun, W. (2012). Manajemen Sumber Daya Manusia. Manajemen Sumber Daya Manusia.

Den Hartog, D. N., \& Verburg, R. M. (2004). High performance work systems, organisational culture and firm effectiveness. Human Resource Management Journal. https://doi.org/10.1111/j.1748-8583.2004.tb00112.x

Dewi, P., \& Netra, I. (2015). Pengaruh Stres Kerja Dan Motivasi Kerja Terhadap Kepuasan Kerja Karyawan Pada Matahari Bungalow Restaurant And Spa Legian Kuta-Bali. EJurnal Manajemen Universitas Udayana.

Dhania, D. R. (2010). Pengaruh Stres Kerja , Beban Kerja Terhadap Kepuasan( Studi Pada Medical Representatif Di Kota Kudus ). Jurnal psikologi Universitas Muria Kudus.

Douglas. (2010). Manajemen Kas. Jakarta: Pustaka Binaman Pressindo.

Gelade, G. A., \& Ivery, M. (2003). The impact of human resource management and work climate on organizational performance. Personnel Psychology. https://doi.org/10.1111/j.1744-6570.2003.tb00155.x

Ghozali, I. (2015). Aplikasi Analisis Multivariate Dengan Program IBM dan SPSS 16. Aplikasi Analisis Multivariate dengan Program IBM dan SPSS 16. https://doi.org/10.1017/CBO9781107415324.004

Habibi, J., \& Jefri. (2018). Analisis Faktor Risiko Stres Kerja Pada Pekerja Di Unit Produksi Pt. Borneo Melintang Buana Export. Journal of Nursing and Public Health.

Han, C., \& Ketut Netra, I. (2014). Pengaruh Konflik Terhadap Stres Kerja dan Kepuasan Kerja Karyawan. E-Jurnal Manajemen Universitas Udayana.

Irvianti, L. S. D., \& Verina, R. E. (2015). Analisis Pengaruh Stres Kerja, Beban Kerja dan Lingkungan Kerja terhadap Turnover Intention Karyawan pada PT XL Axiata Tbk Jakarta. Binus Business Review. https://doi.org/10.21512/bbr.v6i1.995

Koopmans, L. (2014). Measuring Individual Work Performance. In Book.

Lindawati, R. (2014). Work Stress ( Stres Kerja ). Widyaiswara Pusdiklat Bea dan Cukai.

Musliha Fitri, A. (2013). Analisis Faktor-faktor yang Berhubungan dengan Kejadian Stres Kerja pada Karyawan Bank (Studi pada Karyawan Bank Bmt). Jurnal Kesehatan Masyarakat Universitas Diponegoro.

Notoatmojo, S. (2010). Pengembangan Sumber daya manusia. Jurnal LPPM Bidang EkoSosBudKum.

Othman, N. M. B. (2015). Pengaruh Tahap Stres Terhadap Kepuasan Kerja Dalam Kalangan Pengajar Kolej Vokasional Di Negeri Pahang. Universiti Tun Hussein Onn Malaysia. https://doi.org/10.1017/CBO9781107415324.004

Prihatini, L. D. (2008). Analisis hubungan beban kerja dengan stress kerja perawat di tiap ruang rawat inap rsud sidikalang. Stress: The International Journal on the Biology of Stress.

Rambli Bin Haji Hasbi. (2001). Perkaitan Kepuasan Kerja Dengan Prestasi Kerja Di Kalangan Pekerja Di Industri Pembuatan. Fakulti Sains Kognitif dan Pembangunan Manusia 
Universiti Malaysia Sarawak.

Setiyana, V. (2013). Forgiveness Dan Stres Kerja Terhadap Perawat. Jurnal Ilmiah Psikologi Terapan.

Sugiyono. (2016). Metode Penelitian dan Pengembangan (Research and Development/R\&D). In Bandung: Alfabeta. https://doi.org/10.1016/j.drudis.2010.11.005

Sugiyono. (2017). Pendekatan Kuantitatif, Kualitatif, Kombinasi, R\&D dan Penelitian Evaluasi. Bandung: Alfa Beta.

Sunarsi, D. (2018). Pengaruh Kompensasi, Komunikasi Dan Stress Kerja Terhadap Prestasi Kerja Karyawan Pada PT Catur Putra Jaya Kota Depok-Jawa Barat. JIMF (Jurnal Ilmiah Manajemen Forkamma), 1(2).

Tunjungsari, P. (2011). Pengaruh Stress Kerja Terhadap Kepuasan Kerja Karyawan Pada Kantor Pusat PT. POS INDONESIA (PERSERO) BANDUNG. Universitas Komputer Indonesia.

Wartono, T. (2017). Pengaruh Stres Kerja Terhadap Kinerja Karyawan (Studi Pada Karyawan Majalah Mother and Baby). Jurnal Ilmiah Prodi Manajemen Universitas Pamulang.

Waspodo, A. A., Handayani, N. C., \& Paramita, W. (2013). Pengaruh Kepuasan Kerja dan Stres Kerja terhadap Turnover Intention pada Karyawan PT. Unitex di Bogor. Jurnal Riset Manajemen Sains Indonesia (JRMSI).

Wibowo, I. G. P., Riana, G., \& Putra, M. S. (2015). Pengaruh Stres Kerja terhadap Kepuasan Kerja dan Komitmen Organisasional Karyawan. Jurnal Ekonomi dan Bisnis.

Yani, M. (2011). Manajemen Sumber Daya Manusia. Jurnal Perspektif. https://doi.org/ISSN $1411-8637$ 